\title{
Education in Developing Countries Facing Covid-19 Pandemic: Assessment and Evaluation Process Conducted by Lectures in Indonesia
}

\author{
Faisal Faliyandra ${ }^{1}$, Fathor Rosi ${ }^{2}$, Mulyono $^{3}$, Azisi ${ }^{4}$, Zainal Arifin ${ }^{5}$ \\ \{faisalfaliyandra@gmail.com¹, fathorrosy1991stainh@gmail.com² ${ }^{2}$, yonie12mulyono@gmail.com³
} faizanur894@gmail.com ${ }^{4}$, zainalarifinstainh@gmail.com ${ }^{5}$ \}

STAI Nurul Huda Kapongan Situbondo, Indonesia ${ }^{1,2,3,4,5}$

\begin{abstract}
This article aims to examine how the assessment and evaluation process used by lecturers during the covid-19 pandemic. The research was conducted from May to July 2020, with online surveys given to 6 Districts in East Java Province (Tapal Kuda) through social media such as WhatsApp and Telegram, with random system assisted by Google Form. A total of 14 lecturers filled out online sheets spread across 4 districts of East Java Province, Indonesia. Mobile phones are used to further interview informant answers on google form. Qualitative approaches with descriptive techniques are used to broaden the discussion. The findings of this study explain the assessment used by lecturers during the covid-19 pandemic is still traditional by using essays, multiple choices, questionnaires without the use of electronic assessments. However, in the assessment there are various problems, such as poor internet access that impacts the absence of students, incomprehension of the material on the assignment, and the low understanding of the students on the social media applications usage. To solve the problem of assessment, the average lecturer overcomes it by communicating directly to students or parents via mobile phone that can still be used to all corners of remote village. This proves that in rural areas with lack of internet access, communication between educators and students can use mobile phones to help prose learning.
\end{abstract}

Keywords: Educational evaluation; educational technology; distance learning

\section{Introduction}

Since the issuance of the announcement of the Covid-19 Pandemic by WHO, all life processes in this world have changed. This impact also affects the educational process in 46 countries that has changed from school to home using distance learning [1]. The effect of changes in the educational process is very visible in developing countries that experience distance learning problems during the Covid-19 pandemic [2]-[6]. One of the problems in developing countries is the regulation and use of internet technology that is worse than advanced countries [7], [8]. So that distance education during the Covid-19 pandemic must be of particular concern in developing countries. 
Indonesia is a developing country that has 62 underdeveloped districts in 62 districts with the same problem, namely poor internet access coverage in villages[9], [10]. Since the issuance of the Ministry of Education and Culture (Kemendikbud) regulation regarding the Implementation of Policies in an Emergency Period for the Spread of Corona Virus as stated in Circular Number 4 of 2020, a new chapter has begun to change the educational process in Indonesia. This change has an impact on education units from primary school to college education to carry out the distance learning process [11]-[13]. So that in the hope of making learning effective during the Covid-19 pandemic, distance learning is used [14]. However, in Indonesia, this distance learning process is too fast. So that many problems arise [15].

The problem of distance learning that arise such as; technology understanding used[16], the difficulty to understand the material because the Internet is not good [17], maximal attendance of learners [18]. The impact of distance learning problems will lead to the change in assessment and evaluation materials that will be carried out by educators [19]-[21]. This assessment and evaluation is very interesting and important to research because assessment is the final process that must be carried out by lecturers to determine the success of a learning process [22], [23]. Especially during this corona virus pandemic, the assessment and evaluation of lecturers in each lesson must be different from previous conventional learning [24].

A number of research on assessment and evaluation of distance learning has a lot to do in the world of education, about the evaluation techniques [25]. However, very few sources describe exploring problems and solutions for assessment and evaluation during the Covid-19 pandemic. So there are three things that are important to study in the assessment and evaluation of the Covid-19 pandemic, namely; 1. about the assessment techniques used by educators, 2. problems faced during the assessment process, 3. solutions used by educators to face assessment and evaluation problems during the Covid-19 pandemic. These three studies are what differentiate and explain from previous research. So that in this article an in-depth study will be carried out using a qualitative approach to lecturers who are in Tapal Kuda, East Java Province (Pasuruan, Probolinggo, Lumajang, Jember, Situbondo, Bondowoso, and Banyuwangi Regencies). Thus the purpose of this study is to determine the problems of assessment and evaluation and to provide solutions for the Covid-19 pandemic in Indonesia.

\section{Methodology}

This research uses qualitative research with descriptive methods that to found out the evaluation and assessment process carried out by lecturers during the covid-19 pandemic. The purpose of this research to know the assessment process, problems, and solution conducted by lecturers during the covid-19 pandemic. This study took place during May to July 2020. Technical sample used in this study is a cluster random sampling due to the sample selection based on the group that has been determined in the study of Tapal Kuda area in East Java province. Election samples using tools google form withs Ampel consisted of lecturers in Situbondo (4 lecturer of Islamic University (STAI) Nurul Huda Kapongan Situbondo), Banyuwangi (7 professor at the PGRI University of Banyuwangi and 1 lecturer at the Bakti University of Indonesia), Jember Regency (1 lecturer from Islamic Institute of Al-Falah AsSunniyyah Kencong, Jember), and East Kalimantan (1 lecturer from the University of Borneo Tarakan). 


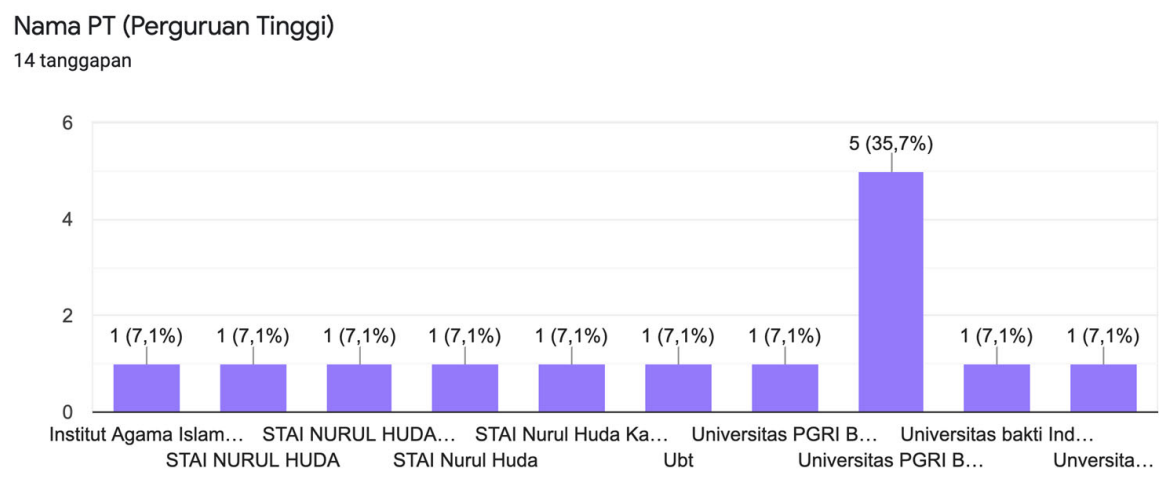

Fig. 1. The percentage of research samples using google form

The lecturers will be given online interviews with open-ended questions using google form. Cell phones were used to interview several informants regarding further answers on the google form. In the open interview, it contains instructions to provide an overview of the problems of assessing and evaluating distance learning during the Covid-19 pandemic. The interview contains four basic questions, namely: 1 . The assessment and evaluation techniques used, 2. Problems encountered during the assessment and evaluation process, 3 . The solution used is the problem of the assessment and evaluation process.

The data analysis used consists of three stages, namely; 1 . Display data by summarizing data obtained from online interviews into one unit, 2 . Reducing data by simplifying a few sentences so that they can be understood. For unnecessary data then eliminated so that it can be grouped into the table that has been made, 3. Make conclusions from the results of the display and reduction about the themes, differences, and similarities that appear the most.

\section{Results}

There are exploratory results from three interview questions; 1 . Assessation process used by lectures during the covid-19 pandemic; 2 . The lectures's problem with using judgment during the covid-19 pandemic; 3 . The lectures's solution for deadling with assessment issues during the covid-19 pandemic.

\subsection{Lecturers Assessment}

Table 1. Summary from google form related to assessment and evaluation in the distance learning system during the corona virus pandemic.

\begin{tabular}{lcccccccccccccc}
\hline \multicolumn{1}{c}{ Techniques } & $\mathbf{1}$ & $\mathbf{2}$ & $\mathbf{3}$ & $\mathbf{4}$ & $\mathbf{5}$ & $\mathbf{6}$ & $\mathbf{7}$ & $\mathbf{8}$ & $\mathbf{9}$ & $\mathbf{1 0}$ & $\mathbf{1 1}$ & $\mathbf{1 2}$ & $\mathbf{1 3}$ & $\mathbf{1 4}$ \\
\hline Multiple choice & - & - & - & - & - & - & $\mathrm{x}$ & - & - & $\mathrm{x}$ & - & - & - & - \\
Essays & - & $\mathrm{x}$ & $\mathrm{x}$ & $\mathrm{x}$ & $\mathrm{x}$ & $\mathrm{x}$ & - & $\mathrm{x}$ & - & - & - & $\mathrm{x}$ & - & $\mathrm{x}$ \\
Questionnaire & $\mathrm{x}$ & - & - & - & - & - & - & - & $\mathrm{x}$ & - & $\mathrm{x}$ & - & - & - \\
Case study & - & - & - & - & - & - & - & - & - & - & - & - & $\mathrm{x}$ & - \\
\hline
\end{tabular}

Table 1, is the conclusion of the answer from question "What techniques were assessed during the distance learning process during the corona virus pandemic?". Form the description of the table above, it can be concluded that the lecturer uses five assessment techniques in 
distance learning, namely essays, questionnaires, multiple choice and case studies. On the whole reason lecturers using five engineering study presented by stating that proses distance learning distance they do because using applications or social media that can not be face to face with students.

This proof can be seen when the average lecturer answers essays as the most effective technique in the distance learning process (lecturers $2,3,4,5,6,8,12,14$ ). Then followed by an assessment technique using a questionnaire (lecturers 1.9 and 12), then multiple choice (lecturers 7 and10) and case studies (lecturers13). Then for the interview assessment technique and it was not chosen by the lecturer on the grounds that it was not limited to social media. There are several reasons the lecturer wrote in the comments column. Lecturer 3 "I cannot use direct observation and interviews with students because online learning is used mostly using WhatsApp Group". Lecturer 6, "How do you want to observe students? So far, you only use learning via telephone for homework. Where possible we use WhatsApp Group to communicate with students. Then lecturer 10 "All I can do is distribute multiple choice questions and essays to students. Every now and then I distribute questionnaires to students to see student motivation".

\subsection{Assessment and Evaluation Problems}

Table 2. Summary of the problems of the assessment and evaluation process experienced by lecturers in the distance learning system during the corona virus pandemic.

\begin{tabular}{|c|c|c|c|c|c|c|c|c|c|c|c|c|c|c|}
\hline Problem & 1 & 2 & 3 & 4 & 5 & 6 & 7 & 8 & 9 & 10 & 11 & 12 & 13 & 14 \\
\hline Poor student internet access & $\mathrm{x}$ & - & - & $\mathrm{x}$ & $\mathrm{x}$ & - & $\mathrm{x}$ & - & $\mathrm{x}$ & $\mathrm{x}$ & - & $\mathrm{x}$ & $\mathrm{x}$ & $\mathrm{x}$ \\
\hline $\begin{array}{l}\text { There is not enough information } \\
\text { about students on the assessment } \\
\text { sheet }\end{array}$ & - & - & - & - & - & - & - & - & - & - & $\mathrm{x}$ & - & - & - \\
\hline Students cannot use the application & - & $\mathrm{x}$ & - & - & - & - & - & $\mathrm{x}$ & - & - & - & - & - & - \\
\hline $\begin{array}{l}\text { The absence of students in the } \\
\text { assessment process }\end{array}$ & - & - & $\mathrm{x}$ & - & - & - & - & - & - & - & - & - & - & - \\
\hline $\begin{array}{l}\text { Students do not understand the } \\
\text { assignment material }\end{array}$ & - & - & - & - & - & $\mathrm{x}$ & - & - & - & - & - & - & - & - \\
\hline
\end{tabular}

Table 2 is the conclusion of the answer from question "What problems were experienced during the assessment and evaluation process of distance learning during the corono virus pandemic?". From the results of the explanation above, many problems arose during the assessment process during the Covid-19 pandemic. These problems are like the bad internet in student areas (lecturers number 1, 4, 5, 7, 9, 10, 12, 13 and 14), students cannot use applications (lecturers number 2 and 8 ), there is not enough information to students (lecturer number 11), the absence of students in the assessment process (lecturer number 3 ) and students not understanding the assignment material (lecturer number 6). Based on some of the data collected in table 2 above, it can be concluded that the main problem faced by lecturers when conducting assessments and evaluations during the corona virus pandemic was poor internet access used by rural students. Poor internet access can cause quite complex problems such as students who do not have motivation to learn applications, the absence of students in the assessment process, students do not understand the material described by the lecturer. 
Several lecturers' explanations were based on the information obtained. Lecturer 1 explained the problem as follows, "students in rural areas are not the same as students in cities who have easy internet access, making it difficult for us to communicate and assign assignments. When we give assignments to student A, we have to entrust them to student B". Opinion of Lecturer 4 "In my opinion, a very visible problem is communicated between the lecturer and the students. This is because internet access is hard to come by students who live in the countryside". Lecturer 9 "we lecturers in rural areas are very difficult to give assignments when students are not present because internet access is very difficult to obtain".

\subsection{Solutions Facing Assessment and Evaluation}

Table 3. Solutions made by lecturers to overcome the problems of the assessment and evaluation process in the distance learning system during the corona virus pandemic

\begin{tabular}{llllllllllllllll}
\hline Metod of dealing with problems & 1 & $\mathbf{2}$ & $\mathbf{3}$ & $\mathbf{4}$ & $\mathbf{5}$ & $\mathbf{6}$ & $\mathbf{7}$ & $\mathbf{8}$ & $\mathbf{9}$ & $\mathbf{1 0}$ & $\mathbf{1 1}$ & $\mathbf{1 2}$ & $\mathbf{1 3}$ & $\mathbf{1 4}$ \\
\hline Online notification letter to parents & - & - & - & $\mathrm{x}$ & - & - & - & - & - & - & - & - & - & - \\
Increase motivation of the students & $\mathrm{x}$ & $\mathrm{x}$ & $\mathrm{x}$ & - & $\mathrm{x}$ & $\mathrm{x}$ & $\mathrm{x}$ & $\mathrm{x}$ & $\mathrm{x}$ & $\mathrm{x}$ & $\mathrm{x}$ & $\mathrm{x}$ & $\mathrm{x}$ & $\mathrm{x}$ \\
\hline
\end{tabular}

Table 3 is the conclusion of the answer from question "The solution used do deal with problems during the assessment and evaluation process of distance learning during corona virus pandemic?". The conclusion is that lecturers are always in touch with students to increase motivation. Communication messages such as notifications to parents, motivation and homework for students.

Some of the lecturers' explanations when answering questions. Lecturer 7 "I ask for help from the families of students who can still be reached by internet access via telephone". Lecturer 9, "Even though there are some students living in remote villages that are far from the internet, I can reach them by telephone. Lecturer 13 "I always communicate with students via cell phone which is assisted by the help of the surrounding community conveying messages and assignments to be given to students".

\subsection{Discussion}

This study wants to explore the assessment and evaluation process used by lecturers during the corona virus pandemic (Covid-19). There are three important findings from the research that has been done.

First, regarding the assessment and evaluation techniques carried out by lecturers during the Covid-19 pandemic. The results prove that there are 4 techniques used by the lecturers, among others; 1.essay, 2. questionnaires, 3. multiple choice, and 4. case studies. These four techniques illustrate that the only assessments that can be seen by lecturers during the corona virus pandemic are on cognitive competence (multiple choice and essays) and student affective (questionnaires and case studies). The use of four techniques have stated that distance learning they do is still traditional [26]. The demands of electronic assessment are highly emphasized on distant learning, because it is more profitable than traditional assessments [27]. This illustrates a meaning that there should be an innovation in distance learning techniques used by lecturers in developing countries, especially Indonesia.

Second, regarding the problems experienced by lecturers when carrying out the assessment process during the corona virus pandemic. The results show that the problems are such as poor 
student's internet connection, there is not enough information about students, some students cannot use the application, students do not attend the assessment process, and students do not understand the material of the assignment. If we draw a conclusion, the main focus of the problem actually lies in students' poor internet access in the field. In villages, internet access is very poor [28], [29], with poor internet access it has an impact on various factors, namely ineffective interpersonal communication and poor community motivation to find out about technological updates [30]. Especially when the informants who provided the data were mostly in Situbondo Regency which was once designated as a disadvantaged area by the Indonesian village ministry. Then this research correlates with the ratings that Indonesia has rural areas with problems in the use of technology in education access [31]. One of the problems in developing countries with underdeveloped areas is access to technology and the Internet are less comprehensive [8]-[10], [32].

Third, regarding the solutions used by lecturers to deal with assessment problems during the corona virus pandemic (Covid-19). The results show that the lecturers' solution in facing the problem of poor internet access experienced by students is by communicating. Without communication, it will be very difficult to make the learning process successful [33], communication will increase the emotional development of students [34]. So the communication is done using a cell phone. The results of this study correlate with the use of learning technology in an area according to technological developments in a particular area [35]. This proves that when in rural areas where internet access is lacking, communication between teachers and students can still use cell phones to help the learning process.

\section{Conclusion}

The problem in all developing countries is the lack of good internet access they use, which has an impact on the assessment and evaluation process during the Covid-19 pandemic. This impact has a long lead to imperfect final competence of the learning process to be achieved. In Indonesia itself, as a developing country, there are three final competences of students that must be achieved, namely cognitive, affective, and psychomotor. However, what can be achieved only in cognitive and affective. Barriers to poor student's internet usage in Indonesia have a strong correlation with the inability of students to use applications, there is not enough student information on the assessment process, students do not understand the material, and there are even some students who are not present during the assessment process. This implies that the assessment and evaluation process in developing countries experiences very complex problems that result in imperfect results from the learning process to be achieved. These findings clearly instruct us to seek solutions in the assessment and evaluation process of distance learning in developing countries. Especially in Indonesia itself, the solution can be found when the distance learning process is implemented not before distance learning is implemented. This provides a solution that appears suddenly from every lecturer in Indonesia, such as using a cell phone whose provider can reach villages to communicate with students and parents of students. Therefore, it is very important researchers further undertake research e-learning using mobile phone communication help to see the impact the success of an experimental basis, in order to complete problems assessment process conducted during the pandemic covid-19. 


\section{References}

[1] W. Cao et al., "The psychological impact of the COVID-19 epidemic on college students in China," Psychiatry Res., vol. 287, p. 112934, 2020, doi: 10.1016/j.psychres.2020.112934.

[2] A. Abidah, H. N. Hidaayatullaah, R. M. Simamora, D. Fehabutar, and L. Mutakinati, "The Impact of Covid-19 to Indonesian Education and Its Relation to the Philosophy of 'Merdeka Belajar,'” Stud. Philos. Sci. Educ., vol. 1, no. 1, pp. 38-49, 2020, doi: 10.46627/sipose.v1i1.9.

[3] N. Kapasia et al., "Impact of lockdown on learning status of undergraduate and postgraduate students during COVID-19 pandemic in West Bengal, India," Child. Youth Serv. Rev., vol. 116, p. 105194, 2020.

[4] V. Shenoy, S. Mahendra, and N. Vijay, "COVID 19 lockdown technology adaption, teaching, learning, students engagement and faculty experience," Mukt Shabd J., vol. 9, no. 4, pp. 698-702, 2020.

[5] K. J. B. Talidong and C. M. D. Toquero, "Philippine Teachers' Practices to Deal with Anxiety amid COVID-19," J. Loss Trauma, vol. 0, no. 0, pp. 1-7, 2020, doi: 10.1080/15325024.2020.1759225.

[6] C. M. D. Toquero, "Emergency remote teaching amid COVID-19: The turning point.," Asian J. Distance Educ., vol. 15, no. 1, pp. 185-188, 2020.

[7] M. S. Ben Ali, "Does ICT promote democracy similarily in developed and developing countries? A linear and nonlinear panel threshold framework," Telemat. Informatics, vol. 50, p. 101382, 2020.

[8] J. James, "Mechanisms of access to the Internet in rural areas of developing countries," Telemat. Informatics, vol. 27, no. 4, pp. 370-376, 2010.

[9] A. Koesnandar, "Pengembangan Inovasi Pembelajaran Berbasis Tik pada Sekolah di Daerah 3t Papua dan Papua Barat melalui Pendampingan Jarak Jauh," Kwangsan, vol. 6, no. 2, p. 286944, 2018.

[10] R. Yanuarti and R. Rusman, "Pemanfaatan teknologi informasi dan komunikasi (TIK) oleh guru di sekolah penerima Universal Service Obligation (USO)," J. Penelit. Ilmu Pendidik., vol. 11, no. 2, pp. 69-83, 2019, doi: 10.21831/jpipfip.v11i2.19441.

[11] T. Darmayanti, M. Y. Setiani, and B. Oetojo, "E-Learning on Distance Education: A Concept That Changes Learning Methods in Higher Education in Indonesia," $J$. Pendidik. Terbuka dan Jarak Jauh, vol. 8, pp. 99-113, 2007.

[12] K. M. Lyons, A. Christopoulos, and T. P. Brock, "Sustainable pharmacy education in the time of COVID-19," Am. J. Pharm. Educ., vol. 84, no. 6, 2020.

[13] M. Salehudin, "DAMPAK COVID-19: GURU MENGADOPSI MEDIA SOSIAL SEBAGAI E - LEARNING PADA PEMBELAJARAN JARAK JAUH PENDAHULUAN Di Indonesia , pembelajaran jarak jauh ( PJJ ) bukanlah sesuatu yang baru , sejak ditetapkannya teknologi dalam Pendidikan dan pembelajaran , upay," J. MUDARRISUNA, vol. 10, no. 1, pp. 1-14, 2020.

[14] G. Basilaia and D. Kvavadze, "Transition to online education in schools during a SARS-CoV-2 coronavirus (COVID-19) pandemic in Georgia.," Pedagog. Res., vol. 5, no. 4, 2020.

[15] Mailizar, A. Almanthari, S. Maulina, and S. Bruce, "Secondary school mathematics teachers' views on e-learning implementation barriers during the COVID-19 pandemic: The case of Indonesia," Eurasia J. Math. Sci. Technol. Educ., vol. 16, no. 7, 2020, doi: 10.29333/EJMSTE/8240. 
[16] A. Purwanto et al., "Studi Eksploratif Dampak Pandemi COVID-19 Terhadap Proses Pembelajaran Online di Sekolah Dasar," EduPsyCouns J. Educ. Psychol. Couns., vol. 2, no. 1, pp. 1-12, 2020.

[17] D. H. Oktawirawan, "Faktor pemicu kecemasan siswa dalam melakukan pembelajaran daring di masa pandemi covid-19," J. Ilm. Univ. Batanghari Jambi, vol. 20, no. 2, pp. 541-544, 2020.

[18] R. S. Safitri and M. Retnasary, "Strategi Komunikasi Guru SMA Alfa Centauri Bandung Masa Pembelajaran Online di Situasi Pandemi COVID-19," Komunikologi J. Pengemb. Ilmu Komun. dan Sos., vol. 4, no. 1, pp. 64-77, 2020.

[19] M. Iskenderoglu, T. A. Iskenderoglu, and M. Palanci, "Opinion of Teaching Staff in Distance Education Systems, Regarding the Assessment and Evaluation Process," Procedia - Soc. Behav. Sci., vol. 46, pp. 4661-4665, 2012, doi: 10.1016/j.sbspro.2012.06.314.

[20] D. Lawton et al., "Online learning based on essential concepts and formative assessment," J. Eng. Educ., vol. 101, no. 2, pp. 244-287, 2012, doi: 10.1002/j.21689830.2012.tb00050.x.

[21] A. Niwaz, W. Q. Ahmed, and S. Kamran, "An Exploration of Issues and Challenges Faced by Students in Distance Learning Environment," Glob. Soc. Sci. Rev., vol. 04, no. 04, pp. 77-83, 2019.

[22] G. G. Berridge, S. Penney, and J. Wells, "eFACT: Formative assessment of classroom teaching for online classes," Turkish Online J. Distance Educ., vol. 13, no. 2, pp. 119130, 2012.

[23] M. Keinänen, J. Ursin, and K. Nissinen, "How to measure students' innovation competences in higher education: Evaluation of an assessment tool in authentic learning environments," Stud. Educ. Eval., vol. 58, no. May, pp. 30-36, 2018, doi: 10.1016/j.stueduc.2018.05.007.

[24] E. Garira, "Needs assessment for the development of educational interventions to improve quality of education: A case of Zimbabwean primary schools," Soc. Sci. Humanit. Open, vol. 2, no. 1, p. 100020, 2020.

[25] J. W. Gikandi, D. Morrow, and N. E. Davis, "Online formative assessment in higher education: A review of the literature," Comput. Educ., vol. 57, no. 4, pp. 2333-2351, 2011.

[26] G. Crisp, L. Guàrdia, and M. Hillier, "Using e-Assessment to enhance student learning and evidence learning outcomes," Int. J. Educ. Technol. High. Educ., vol. 13, no. 1, p. 18, 2016, doi: 10.1186/s41239-016-0020-3.

[27] I. Koneru, "Exploring Moodle functionality for managing open distance learning eassessments," Turkish Online J. Distance Educ., vol. 18, no. 4, pp. 129-141, 2017.

[28] I. Pavez, T. Correa, and J. Contreras, "Meanings of (dis) connection: Exploring nonusers in isolated rural communities with internet access infrastructure," Poetics, vol. 63, pp. 11-21, 2017.

[29] F. Williams, L. Philip, J. Farrington, and G. Fairhurst, “'Digital by Default' and the 'hard to reach': Exploring solutions to digital exclusion in remote rural areas," Local Econ., vol. 31, no. 7, 2016, doi: 10.1177/0269094216670938.

[30] K. Salemink, D. Strijker, and G. Bosworth, "Rural development in the digital age: A systematic literature review on unequal ICT availability, adoption, and use in rural areas," J. Rural Stud., vol. 54, pp. 360-371, 2017, doi: 10.1016/j.jrurstud.2015.09.001.

[31] A. Habibi, A. Mukminin, and P. Hadisaputra, "Science teachers' integration of digital resources in education: a survey in rural areas of one Indonesian province," Heliyon, 
vol. 6, no. 8, p. e04631, 2020.

[32] S. Park, "Digital inequalities in rural Australia: A double jeopardy of remoteness and social exclusion," J. Rural Stud., vol. 54, pp. 399-407, 2017, doi: 10.1016/j.jrurstud.2015.12.018.

[33] N. Duta, G. Panisoara, and I.-O. Panisoara, "The Effective Communication in Teaching. Diagnostic Study Regarding the Academic Learning Motivation to Students," Procedia - Soc. Behav. Sci., vol. 186, pp. 1007-1012, 2015, doi: 10.1016/j.sbspro.2015.04.064.

[34] N. A. Majid, Z. M. Jelas, N. Azman, and S. Rahman, "Communication skills and work motivation amongst expert teachers," Procedia-Social Behav. Sci., vol. 7, pp. 565-567, 2010.

[35] S. Areepattamannil and M. S. Khine, "Early adolescents' use of information and communication technologies (ICTs) for social communication in 20 countriesExamining the roles of ICT-related behavioral and motivational characteristics," Comput. Human Behav., vol. 73, pp. 263-272, 2017, doi: 10.1016/j.chb.2017.03.058. 